\title{
Noise Reduction in Ship Engine Room by Optimisation of Muffler Design
}

\author{
Sunarsih ${ }^{1}$, Taufik Fajar Nugroho ${ }^{2}$, Mirfak Yunan Navyazka ${ }^{3}$ \\ (Received: 01 August 2019/ Revised: 05 August 2020 / Accepted: 31 August 2020)
}

\begin{abstract}
— noise level onboard, particularly in the engine room, requires a careful monitor to not causing any disruption or discomfort to the shipboard environment. For monitoring purposes, an appropriate alternative system can be applied if the noise level exceeds the limit set by applicable regulations such as IMO, ABS, and LR. The current research uses computational methods to map noise contours in the engine room and recommends some muffler models to reduce the noise level in the MV Natuna Express engine room. Based on the field measurement, the noise level exceeds the Standards value at a maximum of $110 \mathrm{~dB}$. Mapping and designing of the muffler models were based on the measurement data. Simulation results show that greater transmission loss hence noise reduction is affected significantly by the expansion of muffler chamber length and diameter. Modification of the muffler chamber using plywood and the tailpipe on both ME ON Generator ON and ME OFF Generator ON conditions respectively reduce the noise approximately by $24.94 \mathrm{~dB}$ and $10.50 \mathrm{~dB}$.
\end{abstract}

Keywords — engine room, muffler design, ship noise, transmission loss.

\section{INTRODUCTION}

$\mathrm{N}$ oise is a problem that is quite important, especially concerning the comfort of the engine room on the ship. The biggest source of noise in the ship is in the engine room. Examples of noise that directly affect the comfort of the crew and all passengers, among others, come from the main engine room itself, which is the largest source of noise, then there are exhaust gas outlets on the deck as well as auxiliary machinery and others.

Previous research stated that the crew of the Jaya Niaga vessel experienced complaints because the noise in the engine room was $120 \mathrm{~dB}$, and the IMO standard was 120 $\mathrm{dB}$ [1]. To reduce noise, it is necessary to understand the source characteristics of noise, how to propagate to the entire body of the ship, and how to effectively and economically reduce it. With that, it is necessary to reduce noise by using a muffler or exhaust gas in the main engine room, so that the sound obtained becomes a healthy environment. There was also a past study stated that the noise level in KMP. Dharma Rucitra is under predetermined standards that do not exceed $102 \mathrm{~dB}$ and produce a contour pattern that clearly shows the components that have the highest and lowest noise levels. The study produced a contour pattern that clearly shows the components that have the highest and lowest noise levels and outlined a method to reduce the noise efficiently by redesigning the muffler [2]. Whereas in other studies, it was stated that the recommended noise level standard for crew cabins based on IMO recommendations is $60 \mathrm{~dB}$ while the measured noise level is $70,78 \mathrm{~dB}$ at points 9 and $70,16 \mathrm{~dB}$ at point 10

Sunarsih is with Departement of Marine Engineering, Institut Teknologi Sepuluh Nopember, Surabaya, 60111, Indonesia. E-mail: sunarsihits@gmail.com

Taufik Fajar Nugroho is with Departement of Marine Engineering, Institut Teknologi Sepuluh Nopember, Surabaya, 60111, Indonesia. Email: tfnugroho@gmail.com

Mirfak Yunan Navyazka is with Departement of Marine Engineering, Institut Teknologi Sepuluh Nopember, Surabaya, 60111, Indonesia. E-mail: mirfakyunannavyazka@yahoo.co.id and recommended mufflers to reduce noise efficiently and optimally [3]. A study on noise reduction disclosed that plywood is well used as a noise controller because plywood has a large mass so that it has a high enough transmission loss (TL) and can reduce vibration propagation. Another material, such as foam and fiber layer, is said to be ineffective due to its low mass and density [4]. An alternative system using plywood as a barrier is proclaimed to be more efficient and possesses the highest TL as compared to other alternative systems [5].

The current research estimates the noise level of the main engine (ME) when the vessel is in ME ON Generator $\mathrm{ON}$ and ME OFF Generator ON conditions via field measurement test and noise mapping method. The current Muffler near the engine and tailpipe were modeled and modified to effectively reduce the noise in the engine room. Recommendations were made based on the most optimum muffler model and configurations.

\section{METHOD}

\section{A. Noise measurement}

The main source of noise on board MV Natuna Express is originated from two main engines and two generators, respectively of $500 \mathrm{~kW}$ and $50 \mathrm{~kW}$ as shown in Figure 1. The port side engine is identified as ME 1, whilst the starboard one is referred to as ME 2. At full speed, the engine speed is respectively $1160 \mathrm{rpm}$ and $1200 \mathrm{rpm}$.

A field test to measure the noise level due to the operation of the engines and generators in the engine room was executed at the point defined by the Standards [6], as illustrated in Figure 2. Following the point, the sound level meter was placed $1 \mathrm{~m}$ above the floor whilst the minimum distance to the equipment to be measured, or the wall is approximately $0,5 \mathrm{~cm}$. During measurement, ME 1 and ME 2 are respectively set at 110 RPM and 145 RPM.

\section{B. Reliability Check and Error Analysis}

Reliability determines the accuracy and precision of a measurement procedure. A reliable instrument measures the desired values hence contribute to testing validity. 

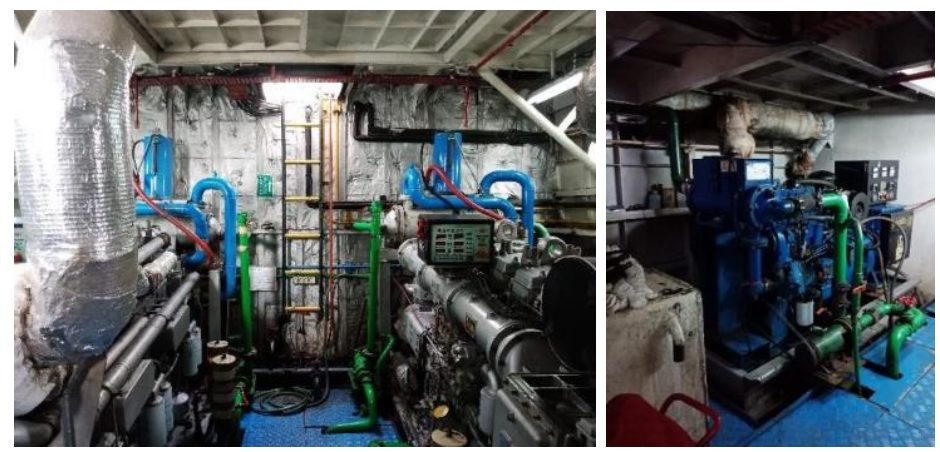

Figure. 1. Main engine (left) and generator set (right) of MV Natuna Express

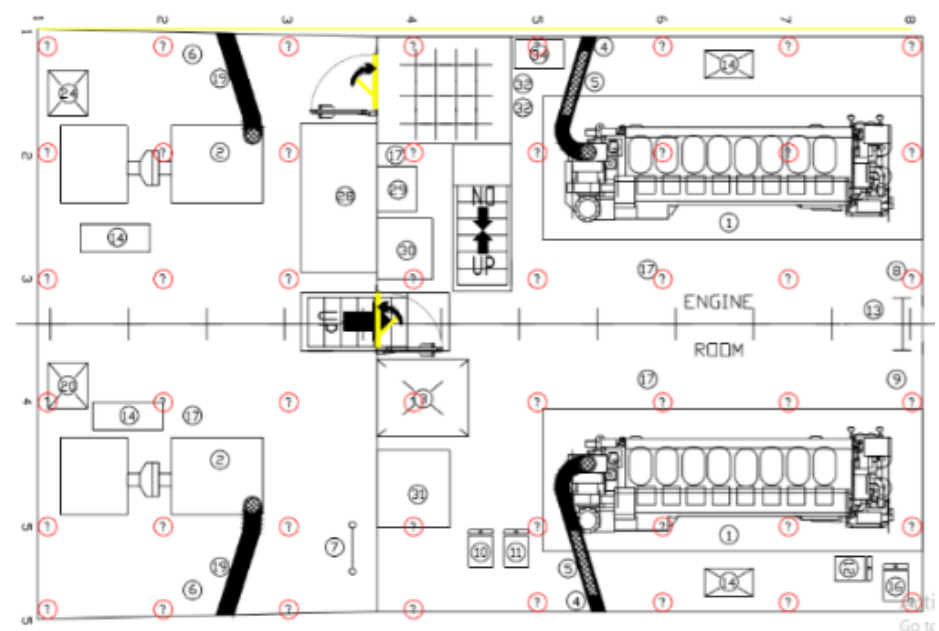

Figure. 2. Noise measurement point for engine room

One of the reliability aspects viz. stability concerns with securing consistent results thru repeated measurement using the same measuring instrument and procedure [7]

In the current study, each measurement of noise level was repeated three times. The noise level was measured at the main engine, generator, and other components operating simultaneously during sailing and anchoring correspond to $\mathrm{ME} \mathrm{ON}$ Generator $\mathrm{ON}$ and $\mathrm{ME} \mathrm{OFF}$ Generator ON conditions. In the earlier condition, both main engines and generator sets were run whilst in the latter, only the generator set was operated.

The stability, precision, and accuracy of the measurement result were examined via error analysis employing two important values, namely, mean $(\bar{X})$ and standard error/deviation $(\sigma)$. The former, which refers to the average of the measured data, reflects the accuracy of the measurement result. Meanwhile, the latter, which denotes the spread of the measured values against the mean, indicates the precision of the data obtained [8].

The study employed an error of $3 \sigma$. This implies that the difference in the measured data is significant if the values $\geq 3 \sigma$ and insignificant if otherwise. Correspondingly, the confidence limit is $\pm 3 \sigma$, which corresponds to a $99.73 \%$ confidence level.

\section{Modeling of Existing Muffler}

The study intended to alternate the existing Muffler into a more efficient design. Modeling of the existing design as initial reference was based on several parameters tabulated in Table 1. Figure 3 displays the

TABLE 1.

MUFFLER MODELING PARAMETERS

\begin{tabular}{|c|c|c|}
\hline No & Parameter & Remarks \\
\hline 1 & Frequency & $\begin{array}{l}\text { The frequency used is the frequency of the Main Engine with a range } \\
\qquad \text { of } 30-1850 \mathrm{~Hz}\end{array}$ \\
\hline 2 & $\begin{array}{c}\text { Length of } \\
\text { Expansion space }\end{array}$ & Length of space expansion on Muffler \\
\hline 3 & $\begin{array}{c}\text { Expansion Space } \\
\text { Diameter }\end{array}$ & The diameter of expansion chamber tube on Muffler \\
\hline 4 & $\begin{array}{l}\text { Diameter of Inlet and } \\
\text { Outlet Pipes }\end{array}$ & Inlet and outlet pipe diameter on Muffler \\
\hline 5 & Inlet Pipe Length & The length of the inlet pipe on the Muffler \\
\hline 6 & Outlet Pipe Length & The length of the inlet pipe on the Muffler \\
\hline
\end{tabular}




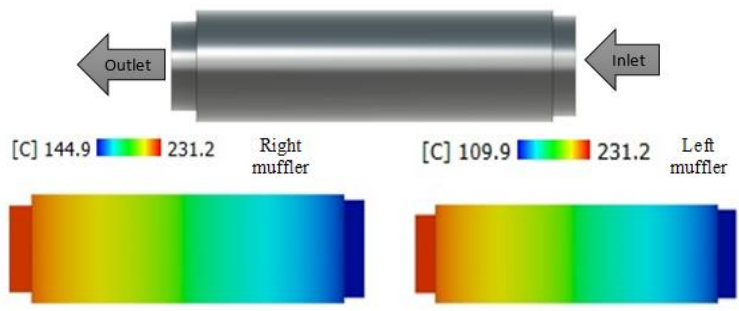

Figure. 3. Existing muffler (up) and the model (down)

existing Muffler and the 3D model produced using the computational method.

\section{Engine Room Noise Mapping}

Noise mapping was carried out based on the measured noise data obtained previously. The study employed a computational method for mapping the noise. This initial noise mapping represents the noise produced by the current engine room machinery systems before any modifications, particularly on the Muffler.

\section{E. Remodeling of Existing Muffler}

Modification of the existing Muffler was performed to both mufflers near the main engine and tailpipe. Four alternative models, referred to as $\mathrm{R}_{1}, \mathrm{R}_{2}, \mathrm{R}_{3}$, and $\mathrm{R}_{4}$, were designed to investigate the optimum dimension in reducing the noise. Two parameters of expansion room length and diameter were chosen as the variable of the remodeling. Table 2 contrasts the dimension of the Muffler alternative designs against the original model, whilst Table 3 correspondingly displays the designs. For $\mathrm{R}$ indicated the right side where the Muffler placed in the engine room, the left side muffler was coded as L. Hence, the four left side mufflers were identified as $L_{1}$, $\mathrm{L}_{2}, \mathrm{~L}_{3}$, and $\mathrm{L}_{4}$.

TABLE 2 .

MODIFIED MUFFLER DIMENSIONS

\begin{tabular}{|c|c|c|c|c|c|}
\hline \multirow{2}{*}{ Parameter } & \multicolumn{5}{|c|}{ Muffler dimension } \\
\hline & Existing & $R_{1}$ & $R_{2}$ & $R_{9}$ & $R_{4}$ \\
\hline $\begin{array}{l}\text { Expansion Room } \\
\text { Length }(\mathrm{cm})\end{array}$ & $310 \mathrm{~cm}$ & $300 \mathrm{~cm}$ & $320 \mathrm{~cm}$ & $320 \mathrm{~cm}$ & $310 \mathrm{~cm}$ \\
\hline $\begin{array}{l}\text { Expansion Room } \\
\text { Diameter }(\mathrm{cm})\end{array}$ & $98 \mathrm{~cm}$ & $88 \mathrm{~cm}$ & $110 \mathrm{~cm}$ & $98 \mathrm{~cm}$ & $110 \mathrm{~cm}$ \\
\hline Intel Pipe Diameter & & & $78 \mathrm{~cm}$ & & \\
\hline Inlet Pipe Length & & & $22 \mathrm{~cm}$ & & \\
\hline $\begin{array}{l}\text { The Diameter of } \\
\text { Outlet Pipe }\end{array}$ & & & $88 \mathrm{~cm}$ & & \\
\hline Outlet Pipe Length & & & $20 \mathrm{~cm}$ & & \\
\hline Pipe Thickness & & & $0.5 \mathrm{~cm}$ & & \\
\hline
\end{tabular}

TABLE 3.

MUFFLER ALTERNATIVE DESIGNS

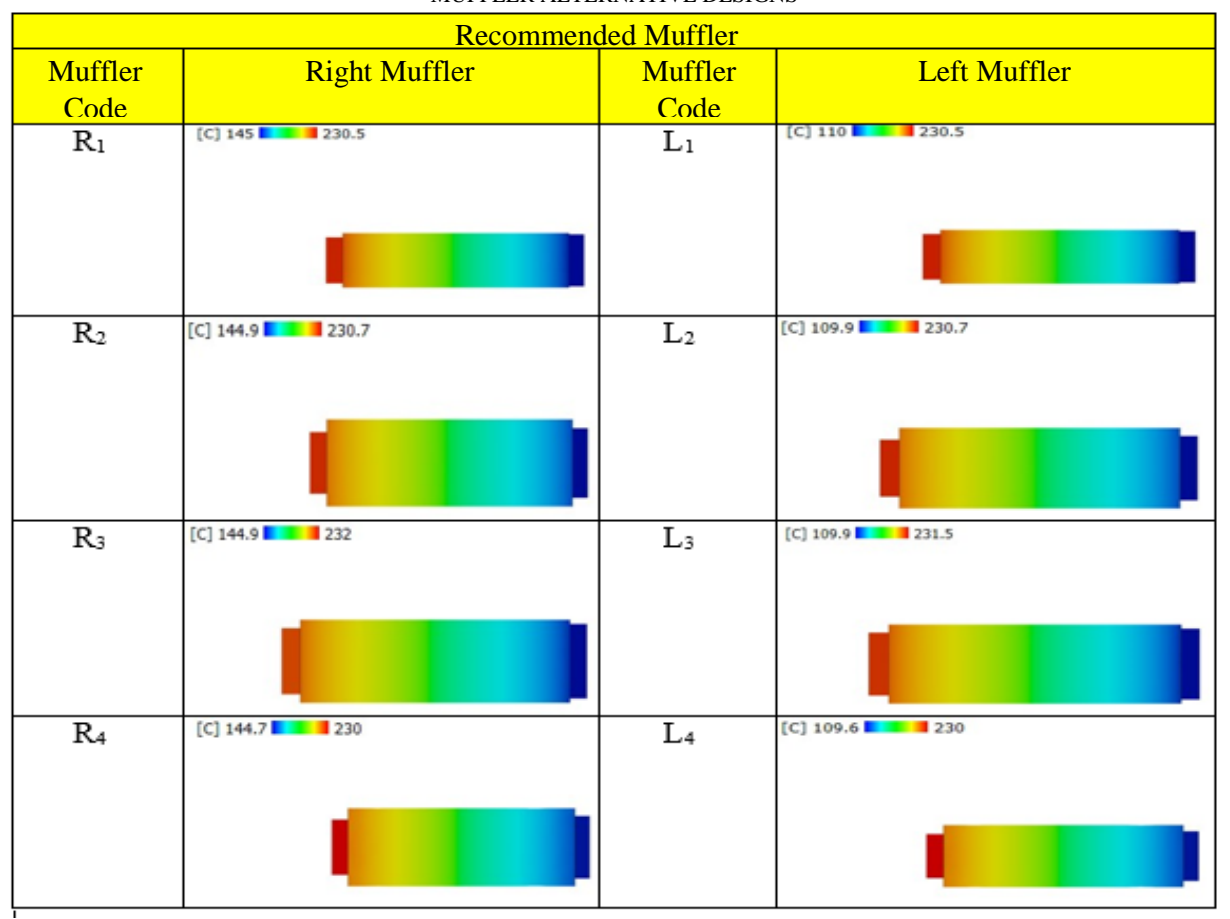




\section{F. Computation of Transmission Loss}

The most optimum muffler design was determined based on the maximum TL value. Manual computation of the value was obtained by using the Plane Wave Assumption given by

$$
\mathrm{TL}=10 \log \left[1+\left(\left(\mathrm{m}^{2}-1\right) /(2 \mathrm{~m}) \sin \mathrm{kl}\right) 2\right]
$$

where

$$
\begin{aligned}
& \mathrm{m} \text { : Comparison of the cross-sectional area of space } \\
& \text { expansion and inlet/outlet pipes } \\
& 1 \text { : Length of the expansion space } \\
& \mathrm{k} \text { : wavenumber }
\end{aligned}
$$

formulated as

\section{$\mathrm{k}=2 \pi \mathrm{freq} / \mathrm{speed}$ of sound}

Simultaneously, the TL value was generated via CFD simulation.

G. Remapping of Engine Room Noise
As the most optimum muffler design identified, the engine room noise was remapped employing the selected design. Remapping was executed on both conditions of $\mathrm{ME} \mathrm{ON}$ Generator $\mathrm{ON}$ and ME OFF Generator ON. Analysis of the noise level prior to and after modification of the Muffler near the main engine and tailpipe was carried out accordingly.

\section{RESULTS AND DISCUSSION}

\section{A. Accuracy of Measurement Data}

The accuracy of the measured noise level in the engine room of MV Natuna Express during ME ON Generator $\mathrm{ON}$ and ME OFF Generator ON representing sailing and anchoring conditions are as shown in Table 4. As seen in the table, all measured data for both conditions satisfy the three standard deviations $(3 \sigma)$ limits. By adopting the statistical criteria defined, a satisfaction of the limit implies that the study is $99,73 \%$ confident that all

\begin{tabular}{|c|c|c|c|c|c|c|c|c|c|c|c|c|c|c|c|c|c|}
\hline \multicolumn{2}{|c|}{$R(x, y)$} & \multicolumn{3}{|c|}{ Noise Level } & \multirow[t]{2}{*}{$\sigma$} & \multirow[t]{2}{*}{$\mathrm{X}-3 \sigma$} & \multirow[t]{2}{*}{$\mathrm{X}+3 \sigma$} & \multirow[t]{2}{*}{ Satisfy } & \multicolumn{2}{|c|}{$R(x, y)$} & \multicolumn{3}{|c|}{ Noige Level } & \multirow[t]{2}{*}{$\sigma$} & \multirow[t]{2}{*}{$\mathrm{X}-3 \sigma$} & \multirow[t]{2}{*}{$\mathrm{X}+3 \sigma$} & \multirow[t]{2}{*}{ Satisfy } \\
\hline$x$ & & $\mathrm{X}_{1}$ & $\mathrm{X}_{2}$ & $\mathrm{X}_{3}$ & & & & & $x$ & & $\mathrm{X}_{1}$ & $\mathrm{X}_{2}$ & $\mathrm{X}_{3}$ & & & & \\
\hline \multirow{5}{*}{0} & 0 & 117,7 & 117,4 & 117,4 & 0,173 & 116,98 & 118,02 & \multirow{5}{*}{$\sqrt{ }$} & \multirow{5}{*}{0} & 0 & 102,1 & 102,2 & 102,3 & 0,100 & 101,90 & 102,50 & \multirow{5}{*}{$\checkmark$} \\
\hline & 1 & 117,7 & 117,9 & 117,9 & 0,115 & 117,49 & 118,18 & & & 1 & 102,6 & 102,2 & 102,1 & 0,265 & 101,51 & 103,09 & \\
\hline & 2 & 115,7 & 115,6 & 115,1 & 0,321 & 114,50 & 116,43 & & & 2 & 103,3 & 103,6 & 103,6 & 0,173 & 102,98 & 104,02 & \\
\hline & 3 & 116,2 & 116,5 & 116,7 & 0,252 & 115,71 & 117,22 & & & 3 & 107,2 & 107,1 & 107,3 & 0,100 & 106,90 & 107,50 & \\
\hline & 4 & 117,5 & 116,6 & 117,2 & 0,458 & 116,98 & 118,47 & & & 4 & 107,1 & 107,7 & 106,9 & 0,416 & 105,98 & 108,48 & \\
\hline \multirow{5}{*}{1} & 0 & 117,2 & 117,7 & 117,5 & 0,252 & 116,71 & 118,22 & \multirow{5}{*}{$\sqrt{ }$} & & 0 & 106 & 110 & 110,2 & 2,369 & 101,63 & 115,84 & \multirow{5}{*}{$\gamma$} \\
\hline & 1 & 117,7 & 117,4 & 117,4 & 0,173 & 116,98 & 118,02 & & & 1 & 105 & 107 & 107 & 1,155 & 102,87 & 109,80 & \\
\hline & 2 & 113,2 & 112,6 & 112,2 & 0,503 & 111,16 & 114,18 & & & 2 & 108 & 108 & 110 & 1,155 & 105,20 & 112,13 & \\
\hline & 3 & 114,2 & 114,3 & 115 & 0,436 & 113,19 & 115,81 & & & 3 & 108,1 & 108,2 & 107,8 & 0,208 & 107,41 & 108,66 & \\
\hline & 4 & 115,6 & 116,2 & 115,2 & 0,503 & 114,16 & 117,18 & & 1 & 4 & 107,2 & 106,7 & 106,5 & 0,361 & 105,72 & 107,88 & \\
\hline \multirow{5}{*}{2} & 0 & 116,3 & 117,9 & 118,5 & 1,137 & 114,15 & 120,98 & \multirow{5}{*}{$\checkmark$} & & 0 & 101,2 & 101,3 & 101,3 & 0,058 & 101,09 & 101,44 & \multirow{5}{*}{$\gamma$} \\
\hline & 1 & 118 & 117,4 & 117,3 & 0,379 & 116,43 & 118,70 & & & 1 & 98,8 & 98,8 & 98,7 & 0,058 & 98,59 & 98,94 & \\
\hline & 2 & 114,5 & 114,1 & 113,8 & 0,351 & 113,08 & 115,19 & & & 2 & 94,2 & 94,1 & 100,1 & 3,436 & 85,83 & 106,44 & \\
\hline & 3 & 112,8 & 113,1 & 113,4 & 0,300 & 112,20 & 114,00 & & & 3 & 105,5 & 105,5 & 105,3 & 0,115 & 105,09 & 105,78 & \\
\hline & 4 & 118,3 & 116 & 116,7 & 1,179 & 113,46 & 120,54 & & 2 & 4 & 108 & 107,8 & 107,7 & 0,361 & 105,72 & 107,88 & \\
\hline & 0 & 115 & 113,5 & 115 & 0,866 & 111,90 & 117,10 & & & 0 & 101,7 & 101,6 & 102,1 & 0,265 & 101,01 & 102,59 & \\
\hline & 1 & 113,5 & 113,9 & 113,5 & 0,231 & 112,94 & 114,33 & & & 1 & 94,5 & 94,6 & 100,1 & 3,205 & 86,79 & 106,01 & \\
\hline 3 & 2 & 112,1 & 111,8 & 111,5 & 0,300 & 110,90 & 112,70 & $\checkmark$ & & 2 & 94,2 & 94,6 & 100,1 & 3,297 & 86,41 & 106,19 & $\checkmark$ \\
\hline & 3 & 113,9 & 114,9 & 115 & 0,608 & 112,78 & 116,42 & & & 3 & 101,5 & 101,8 & 102,9 & 0,737 & 99,86 & 104,28 & \\
\hline & 4 & 117,1 & 116 & 117 & 0,608 & 114,88 & 118,52 & & 3 & 4 & 104,8 & 105,1 & 104,8 & 0,173 & 104,38 & 105,42 & \\
\hline & 0 & 115,5 & 115,3 & 115,2 & 0,153 & 114,88 & 115,79 & & & $\overline{0}$ & 97,6 & 97,7 & 97,5 & 0,100 & 97,30 & 97,90 & \\
\hline & 1 & 114,2 & 115,3 & 115 & 0,569 & 113,13 & 116,54 & & & 1 & 90,6 & 90,4 & 90,5 & 0,100 & 90,20 & 90,80 & \\
\hline 4 & 2 & 113,1 & 113 & 113,2 & 0,100 & 112,80 & 113,40 & $\checkmark$ & & 2 & 88,8 & 88,5 & 88,8 & 0,173 & 88,18 & 89,22 & $\checkmark$ \\
\hline & 3 & 114,1 & 114,2 & 114 & 0,100 & 113,80 & 114,40 & & & 3 & 94,4 & 94,3 & 93,8 & 0,321 & 93,20 & 95,13 & \\
\hline & 4 & 115 & 114,6 & 115,2 & 0,306 & 114,02 & 115,85 & & 4 & 4 & 96,5 & 96,2 & 96,4 & 0,153 & 95,91 & 96,82 & \\
\hline & 0 & 114,3 & 114,9 & 116,8 & 1,305 & 111,42 & 119,25 & & & 0 & 98,6 & 97,8 & 98,3 & 0,404 & 97,02 & 99,45 & \\
\hline & 1 & 114,3 & 114,5 & 114,5 & 0,115 & 114,09 & 114,78 & & & 1 & 90,8 & 90,7 & 90,6 & 0,100 & 90,40 & 91,00 & \\
\hline 5 & 2 & 114,7 & 114,1 & 114,5 & 0,306 & 113,52 & 115,35 & $\sqrt{ }$ & & 2 & 89,1 & 89,2 & 89,1 & 0,058 & 88,96 & 89,31 & $\checkmark$ \\
\hline & 3 & 114,1 & 113,7 & 113,8 & 0,208 & 113,24 & 114,49 & & & 3 & 91,8 & 91,2 & 91,5 & 0,300 & 90,60 & 92,40 & \\
\hline & 4 & 115,3 & 115,1 & 115,3 & 0,115 & 114,89 & 115,58 & & 5 & 4 & 95,3 & 94 & 94,2 & 0,700 & 92,40 & 96,60 & \\
\hline & 0 & 117,7 & 116,8 & 117,7 & 0,520 & 115,84 & 118,96 & & & 0 & 101,4 & 101 & 101,6 & 0,306 & 100,42 & 102,25 & \\
\hline & 1 & 115,6 & 116,4 & 115,7 & 0,436 & 114,59 & 117,21 & & & 1 & 93 & 92,5 & 92,5 & 0,289 & 91,80 & 93,53 & \\
\hline 6 & 2 & 116,7 & 116,4 & 116,9 & 0,252 & 115,91 & 117,42 & $\checkmark$ & & 2 & 89,7 & 89,6 & 89,7 & 0,058 & 89,49 & 89,84 & $\checkmark$ \\
\hline & 3 & 115,3 & 115,5 & 115 & 0,252 & 114,51 & 116,02 & & & 3 & 96,3 & 96,4 & 96 & 0,208 & 95,61 & 96,86 & \\
\hline & 4 & 116,4 & 116,5 & 117 & 0,321 & 115,67 & 117,60 & & 6 & 4 & 100,7 & 101 & 101 & 0,173 & 100,38 & 101,42 & \\
\hline
\end{tabular}
measured noise data are accurate to the stated degree [6] hence reliable for further use throughout the study.

TABLE 4.

ACCURACY OF NOISE LEVEL DATA ON ME ON GENERATOR ON (LEFT) AND ME OFF GENERATOR ON (RIGHT) CONDITIONS

TABLE 5 .

TRANSMISSION LOSSES OF VARIOUS MUFFLER DESIGNS

\begin{tabular}{|c|c|c|c|c|c|}
\hline \multirow{2}{*}{ Parameter } & \multicolumn{5}{|c|}{ Muffler dimension } \\
\cline { 2 - 6 } & Existing & $R_{4}$ & $R_{\mathcal{I}}$ & $R_{\mathrm{I}}$ & $R_{4}$ \\
\hline $\begin{array}{c}\text { Expansion Room } \\
\text { Length }(\mathrm{cm})\end{array}$ & $310 \mathrm{~cm}$ & $300 \mathrm{~cm}$ & $320 \mathrm{~cm}$ & $320 \mathrm{~cm}$ & $310 \mathrm{~cm}$ \\
\hline $\begin{array}{c}\text { Expansion Room } \\
\text { Diameter }(\mathrm{cm})\end{array}$ & $98 \mathrm{~cm}$ & $88 \mathrm{~cm}$ & $110 \mathrm{~cm}$ & $98 \mathrm{~cm}$ & $110 \mathrm{~cm}$ \\
\hline $\begin{array}{c}\text { Temperature Speed } \\
\text { Not Full }\end{array}$ & \multicolumn{5}{|c|}{$110 \mathrm{C}$} \\
\hline $\begin{array}{c}\text { Full Speed } \\
\text { Temperature }\end{array}$ & \multicolumn{5}{|c|}{$230 \mathrm{C}$} \\
\hline Full Speed Round & \multicolumn{5}{|c|}{$1160 \mathrm{rpm}$} \\
\hline Transmission Loss & $24,78 \mathrm{~dB}$ & $24,65 \mathrm{~dB}$ & $24,94 \mathrm{~dB}$ & $24,92 \mathrm{~dB}$ & $24,74 \mathrm{~dB}$ \\
\hline
\end{tabular}




\section{B. Recommended Muffler Model}

The most efficient muffler design was determined based on the maximum TL value. Table 5 displays the TL values of the existing, and the four modified mufflers vary in length and diameter of the expansion room. As shown in the table, muffler $\mathrm{R}_{2}$ possessing a bigger expansion room in both length and diameter, respectively, by $3,23 \%$ and $12,24 \%$ of the existing design, generates the highest TL value by $24.94 \mathrm{~dB}$, which equals to $0,65 \%$ of the existing TL value.

The presented values signify that a bigger expansion room by length is more efficient than the diameter. As evidence, muffler $\mathrm{R}_{3}$ possessing only a 3,23\% longer expansion room, yielded a higher TL value by $0,73 \%$ as compared to muffler $\mathrm{R}_{4}$, which has an even bigger diameter by as much as $12,24 \%$ from an existing design. The earlier design increases the TL value by $0,65 \%$, whilst the latter, unfortunately, decreases the value by $0,16 \%$. Various TL values shown by each design conform with suggestions from previous research who denoted that type and shape of the Muffler and the barrier affect the efficiency of the system indicated by the TL values [5].

\section{Engine Room Noise Contour}

Noise mapping has been executed at two conditions of prior and after modification of the Muffler. At the initial condition prior to system modification, noise contour was yielded from the mapping of the measured noise level. After modification, the contour was generated from the mapping of the modified noise level obtained from the computation of the measured noise level against the TL due to the system modification.

1) Initial Noise Contour

Figure 4 displays the current engine room noise contour on both ME ON Generator $\mathrm{ON}$ and $\mathrm{ME}$ OFF Generator ON conditions.

On the ME ON Generator ON condition, there is only one generator set, which is the right generator (1). ME 1 and ME 2 has a circular noise distribution because it is assumed that the noise distribution is evenly distributed. In the engine room, it is calculated from the coordinates $(\mathrm{x}, \mathrm{y})=$ (4.1) to (7.5) using the calculation of 3 sources, namely $2 \mathrm{ME} \mathrm{ON}$ and $1 \mathrm{ON}$ generator set number 1. The red color to the organism is around the right generator set because it is a source of noise that was around the right generator set is measured $10 \mathrm{~cm}$ from the generator, and the result is $117.8 \mathrm{~dB}$.

The Main engine has an orange color because the engine room has a range of $116-114.2 \mathrm{~dB}$. This is because, in the engine room, there are several windows (Shuttle side) and open manhole positions that are at coordinates $(\mathrm{x}, \mathrm{y})=(7.3)$. Overall the engine room has an average noise level of 111 to $117 \mathrm{~dB}$. Overall the engine room is not following the IMO standard where the engine
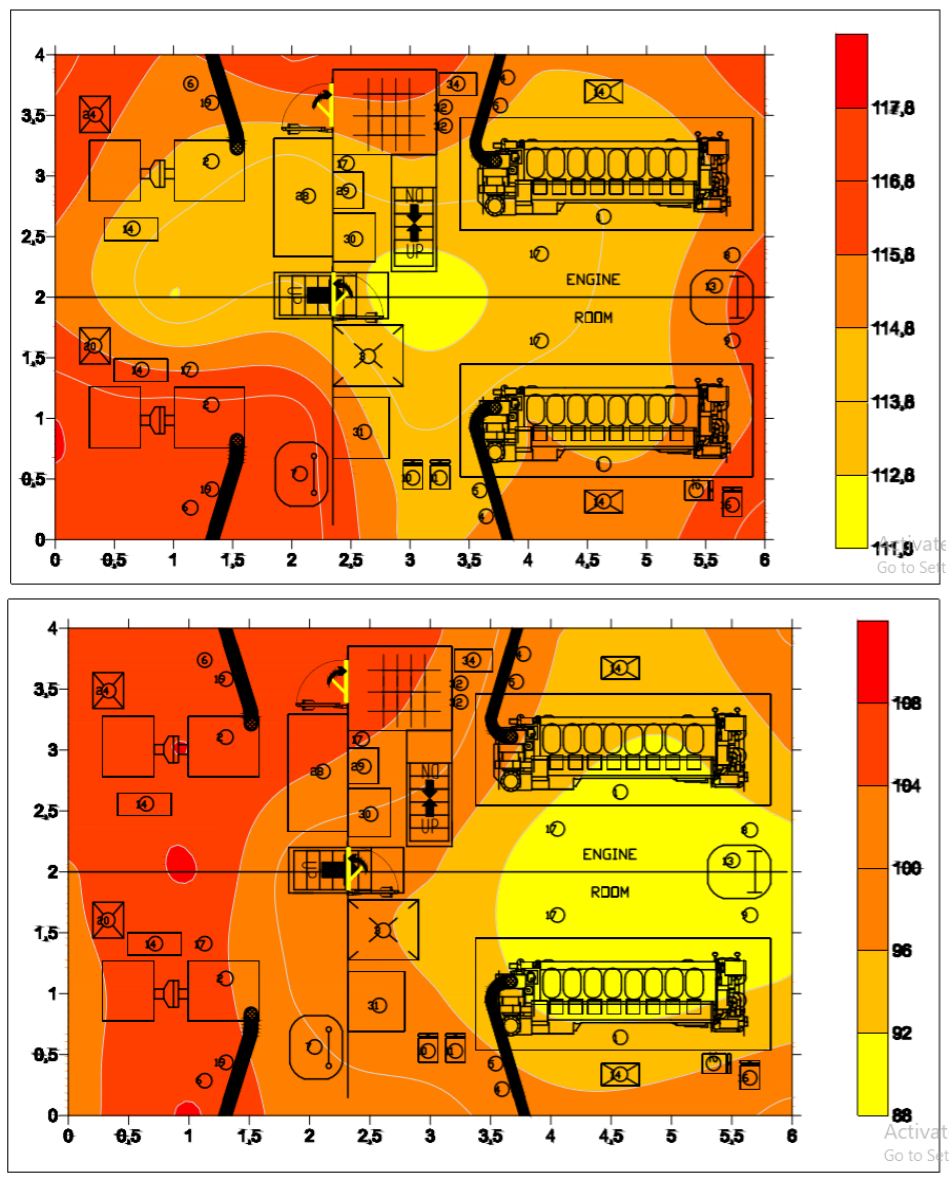

Figure. 4. Current noise contour on ME ON Generator ON (up) and ME OFF Generator ON (down) conditions 
room for noise limits is $110 \mathrm{~dB}$ while the conditions in the field for noise limits are above $111 \mathrm{~dB}$.

On ME OFF Generator ON condition, only one generator set is on the left (1) generator set. The solid red color is found around the left generator because it is a source of noise where around the left generator is measured $10 \mathrm{~cm}$ from the generator, and the result is $108 \mathrm{~dB}$. The main engine has a yellow range with a noise range of $88-92 \mathrm{~dB}$. This is because the condition of the Main engine is off, and in the engine room, there are several windows (Shuttle side) and open position manholes that are at coordinates $(\mathrm{x}, \mathrm{y})=$ (7.3). So that the noise only comes from the sound of the right generator. Overall engine room noise is following the IMO standard if the state of the Main engine OFF and Generator is $\mathrm{ON}$ and where for the engine room for noise limits is 110 $\mathrm{dB}$ based on the International standard while the conditions in the field for noise limits are a maximum of $108.7 \mathrm{~dB}$.

2) Noise Contour of Modified System

Figure 5 and Figure 6 respectively depict the engine room noise contour due to the modification of the Muffler near the main engine and near the tailpipe on both ME ON Generator $\mathrm{ON}$ and ME OFF Generator ON conditions.
As seen from Figure 5 on the ME ON Generator ON condition, there is only one generator set, which is the right generator (1) - in the engine room, calculated from the coordinates $(\mathrm{x}, \mathrm{y})=$ (4.1) to (7.5) using the calculation of 3 sources, namely $2 \mathrm{ME} \mathrm{ON}$ and one generator set $\mathrm{ON}$.

The red color to orange is found around the right generator set because it is a source of noise were around the right generator set is measured $10 \mathrm{~cm}$ from the generator, and the result is $92.9 \mathrm{~dB}$. The main engine has a red color to the organizer because, in the engine room, it has a range of 86.9 - $92.5 \mathrm{~dB}$ after modifying the Muffler on the Main engine. This is because, in the engine room, there are several windows (Shuttle side) and open manhole positions that are at coordinates $(\mathrm{x}, \mathrm{y})=$ (7.3) after modifying the Muffler on the Main engine for the overall noise in the engine room according to the IMO standard where the engine room for noise limit is $110 \mathrm{~dB}$ while the conditions in the field for noise limits are below $92.9 \mathrm{~dB}$.

Correspondingly, on ME OFF Generator ON condition, only one generator set is on the left (1) generator set. The concentrated orange color is found around the left generator set because it is a source of noise where around the left generator is measured $10 \mathrm{~cm}$ from the generator, and the result is $83.1 \mathrm{~dB}$. The main engine has a color to
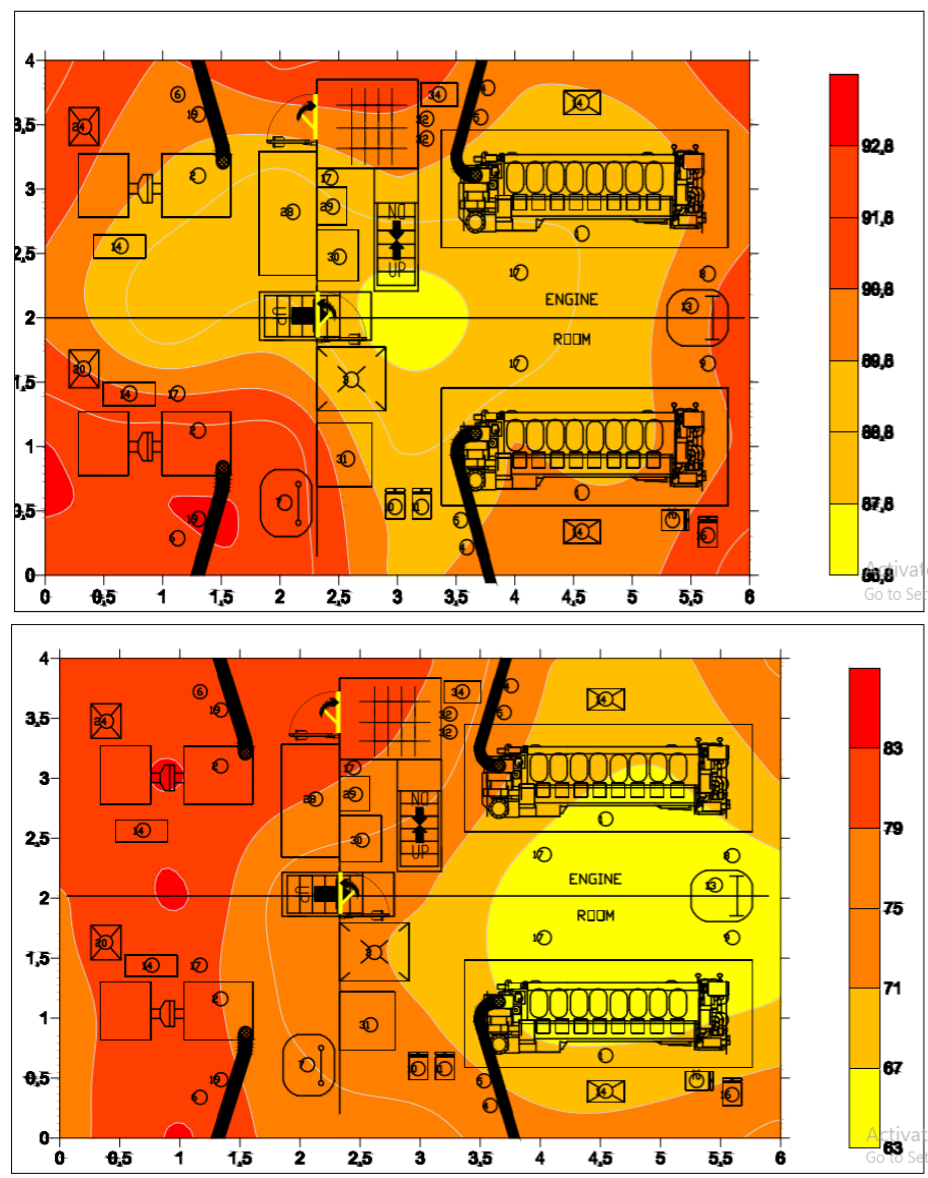

Figure. 5. Noise contour with muffler modification near main engine on ME ON Generator ON (up) and ME OFF Generator ON (down) conditions 
ORENEN with a range of noise of $63.8-80 \mathrm{~dB}$. after modifying the Muffler on the Main engine. This is because, in the engine room, there are several windows (Shuttle side) and open manhole positions that are at coordinates $(x, y)=(7.3)$ after modifying the Muffler on the Main engine for the overall noise in the engine room according to the IMO standard where for the engine room for noise limit is $110 \mathrm{~dB}$ while the conditions in the field for noise limits are below $83.8 \mathrm{~dB}$.

In Figure 6 on the ME ON Generator ON condition, it was shown that there is only one generator set, which is the right generator (1). ME 1 and ME 2 has a circular noise spread because it is assumed that the spread of noise is even. In the engine room, it is calculated from the coordinates $(\mathrm{x}, \mathrm{y})=(4.1)$ to (7.5) using the calculation of 3 sources, namely $2 \mathrm{ME} \mathrm{ON}$ and one generator set ON. Air density also affects noise velocity. In the morning conditions, the air is cold and quickly delivers noise.

Main engines 1 and 2 have the same noise level because of the same RPM. But the engine 1 has a slightly higher noise level because the engine works harder than the Main engine 2. The red color of the engine is around the right generator because it is a source of noise, which is around 10 $\mathrm{cm}$ from the generator, and the result is amounting to $107.1 \mathrm{~dB}$. The highest noise value among all noise values due to high rotation and the sound produced is also very noisy. The Main engine has the color of the original because, in the engine room, it has a range of $101.3-107.3 \mathrm{~dB}$ after experiencing a modified Muffler on a Tail Pipe. This is because, in the engine room, there are several windows (Shuttle side) and open manhole positions that are at coordinates $(\mathrm{x}, \mathrm{y})=$ (7.3). Spread on coordinates $(6,2)$ as in the picture because the calculation uses three sources and has different results a little far from the measurement results in that point so that the contour results obtained are like that. After modifying the Muffler on the Main engine for the overall noise in the engine room according to the IMO standard, the engine room for noise conditions is $110 \mathrm{~dB}$, while the conditions in the field for noise limits are below $107.3 \mathrm{~dB}$.

From the same figure on ME OFF Generator ON condition, it was also shown that only one generator set is on the left (1) generator set. Orange red-orange color is found around the left generator set because it is a source of noise where around the left generator is measured $10 \mathrm{~cm}$ from the generator, and the result is $97.5 \mathrm{~dB}$. The highest noise value among all noise values due to high rotation and the sound produced is also very
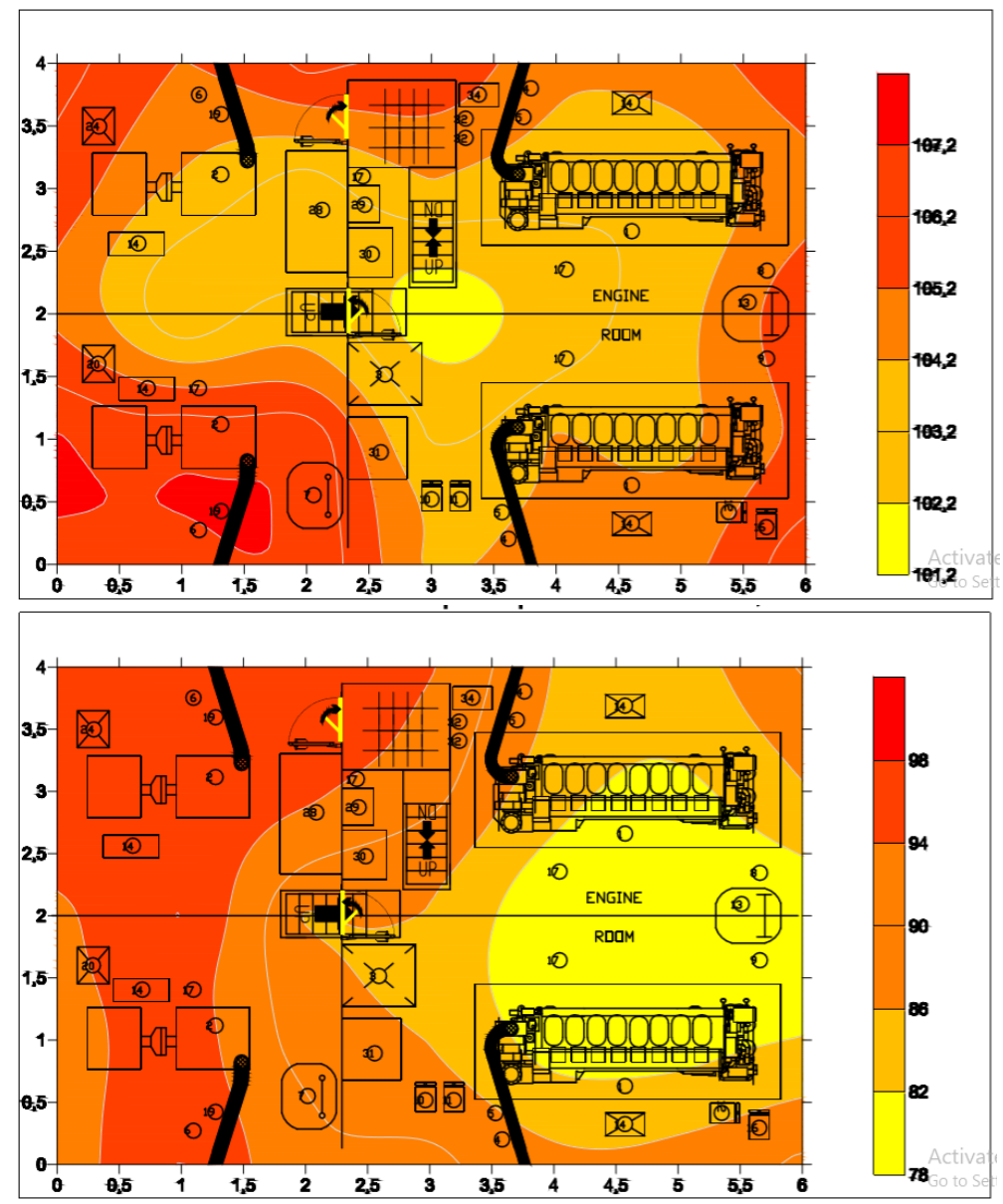

Figure. 6. Noise contour with muffler modification near tail pipe on ME ON Generator ON (up) and ME OFF Generator ON (down) conditions 
noisy. The main engine was colored in orange with a range of noise of $78.2-82.2 \mathrm{~dB}$. after experiencing a modification of the Muffler on a Tail Pipe. This is because, in the engine room, there are several windows (Shuttle side) and open manhole positions that are at coordinates $(\mathrm{x}, \mathrm{y})=$ (7.3).

ME 1 and ME 2 has a circular noise spread because it is assumed that the spread of noise is even. Noise contours form like ocean waves, which are following the nature of noise that is propagated through the air so that the spread is widespread and even. Air density also affects noise velocity. In the morning conditions, the air is cold and quickly delivers noise after modifying the Main engine Muffler for the overall noise in the engine room according to the IMO standard, where the engine room for noise is $110 \mathrm{~dB}$ while the conditions in the field for noise limits are below $98.2 \mathrm{~dB}$.
D. Effect of Muffler Modification on Noise Level

The noise level of the currently installed machinery system obtained from the point by point measurement on ME ON Generator $\mathrm{ON}$ and ME OFF Generator ON conditions was analyzed against the ones from the modified system installing the recommended Muffler as shown in Table 6. Table 7 correspondingly summarised the values prior to and after the modification of the Muffler both near the main engine and tailpipe. Three values comprise maximum, minimum, and average, which were presented for reference.

As seen from the summary in the table, the noise level on both ME ON Generator ON and ME OFF Generator ON conditions decrease after installation of the modified Muffler. The reduction respectively values approximately $21,6 \%$ and $25,0 \%$. The numbers signify that it was easier to downgrade the noise during engine off condition. As a matter of fact, it is reducing the noise of a system having a $500 \mathrm{~kW}$ engine and $50 \mathrm{~kW}$ generator which on certainly a lot harder than handling another system merely running the $50 \mathrm{~kW}$ generator

TABLE 6.

NOISE LEVEL ON ME ON GENERATOR ON (LEFT) AND ME OFF GENERATOR ON (RIGHT) CONDITIONS

\begin{tabular}{|c|c|c|c|}
\hline \multicolumn{2}{|c|}{$R(x, y)$} & \multirow{2}{*}{$\begin{array}{c}\text { Current noise } \\
\text { level }\end{array}$} & \multirow{2}{*}{$\begin{array}{l}\text { Noise level after } \\
\text { muffler modification }\end{array}$} \\
\hline $\mathrm{x}$ & $\mathrm{Y}$ & & \\
\hline \multirow{5}{*}{0} & 0 & 117,5 & 92,6 \\
\hline & 1 & 117,8 & 92,9 \\
\hline & 2 & 115,5 & 90,5 \\
\hline & 3 & 116,5 & 91,5 \\
\hline & 4 & 117,1 & 92,2 \\
\hline \multirow{5}{*}{1} & 0 & 117,5 & 92,5 \\
\hline & 1 & 117,5 & 92,6 \\
\hline & 2 & 112,7 & 87,7 \\
\hline & 3 & 114,5 & 89,6 \\
\hline & 4 & 115,7 & 90,7 \\
\hline \multirow{5}{*}{2} & 0 & 117,6 & 92,6 \\
\hline & l & 117,6 & 92,6 \\
\hline & 2 & 114,1 & 89,2 \\
\hline & 3 & 113,1 & 88,2 \\
\hline & 4 & 117 & 92,1 \\
\hline \multirow{5}{*}{3} & 0 & 114,5 & 89,6 \\
\hline & 1 & 113,6 & 88,7 \\
\hline & 2 & 111,8 & 86,9 \\
\hline & 3 & 114,6 & 89,7 \\
\hline & 4 & 116,7 & 91,8 \\
\hline \multirow{5}{*}{4} & 0 & 115,3 & 90,4 \\
\hline & 1 & 115,3 & 89,9 \\
\hline & 2 & 113,1 & 88,2 \\
\hline & 3 & 114,1 & 89,2 \\
\hline & 4 & 114,1 & 90 \\
\hline \multirow{5}{*}{5} & 0 & 115,3 & 90,4 \\
\hline & 1 & 115,3 & 89,5 \\
\hline & 2 & 114,4 & 89,5 \\
\hline & 3 & 113,9 & 88,9 \\
\hline & 4 & 115,2 & 90,3 \\
\hline \multirow{5}{*}{6} & 0 & 117,4 & 92,5 \\
\hline & l & 115,9 & 91 \\
\hline & 2 & 116,7 & 91,7 \\
\hline & 3 & 115,3 & 90,3 \\
\hline & 4 & 116,6 & 91,7 \\
\hline
\end{tabular}

\begin{tabular}{|c|c|c|c|}
\hline \multicolumn{2}{|c|}{$R(x, y)$} & \multirow{2}{*}{$\begin{array}{c}\text { Current noise } \\
\text { level }\end{array}$} & \multirow{2}{*}{$\begin{array}{c}\text { Noise level after } \\
\text { muffler modification }\end{array}$} \\
\hline $\mathrm{x}$ & $\mathrm{Y}$ & & \\
\hline \multirow{5}{*}{0} & 0 & 102,2 & 77,3 \\
\hline & 1 & 102,3 & 77,4 \\
\hline & 2 & 103,5 & 78,6 \\
\hline & 3 & 107,2 & 82,3 \\
\hline & 4 & 107,2 & 82,3 \\
\hline \multirow{5}{*}{1} & 0 & 108,7 & 83,8 \\
\hline & 1 & 106,3 & 81,4 \\
\hline & 2 & 108,7 & 83,7 \\
\hline & 3 & 108 & 83,1 \\
\hline & 4 & 106,8 & 81,9 \\
\hline \multirow{5}{*}{2} & 0 & 101,3 & 76,3 \\
\hline & 1 & 98,8 & 73,8 \\
\hline & 2 & 96,1 & 71,2 \\
\hline & 3 & 105,4 & 80,5 \\
\hline & 4 & 107,8 & 82,9 \\
\hline \multirow{5}{*}{3} & 0 & 101,8 & 76,9 \\
\hline & 1 & 96,4 & 71,5 \\
\hline & 2 & 96,3 & 71,4 \\
\hline & 3 & 102,1 & 77,1 \\
\hline & 4 & 104,9 & 80 \\
\hline \multirow{5}{*}{4} & 0 & 97,6 & 72,7 \\
\hline & 1 & 90,5 & 65,6 \\
\hline & 2 & 88,7 & 63,8 \\
\hline & 3 & 94,2 & 69,2 \\
\hline & 4 & 96,4 & 71,4 \\
\hline \multirow{5}{*}{5} & 0 & 98,2 & 73,3 \\
\hline & l & 90,7 & 65,8 \\
\hline & 2 & 89,1 & 64,2 \\
\hline & 3 & 91,5 & 66,6 \\
\hline & 4 & 94,5 & 69,6 \\
\hline \multirow{5}{*}{6} & 0 & 101,3 & 76,4 \\
\hline & 1 & 92,7 & 67,7 \\
\hline & 2 & 89,7 & 64,7 \\
\hline & 3 & 96,2 & 71,3 \\
\hline & 4 & 100,9 & 76 \\
\hline
\end{tabular}

TABLE 7.

NOISE LEVEL PRIOR AND AFTER SYSTEM MODIFICATION

\begin{tabular}{cccccccccc}
\hline \multirow{2}{*}{ Condition } & \multicolumn{2}{c}{ Existing System } & \multicolumn{5}{c}{ Modified System } \\
\cline { 5 - 9 } & Near Main Engine $(\mathrm{dB})$ & \multicolumn{2}{c}{ Near Main Engine $(\mathrm{dB})$} & \multicolumn{3}{c}{ Near Tail Pipe $(\mathrm{dB})$} \\
\hline \multirow{2}{*}{ ME ON } & Min & $:$ & 117,8 & Min & $:$ & 92,9 & Min & $:$ & 107,3 \\
Generator ON & Max & $:$ & 112,7 & Max & $:$ & 88,2 & Max & $:$ & 101,3 \\
& Average & $:$ & 115,4 & Average $:$ & 90,5 & Average & 104,9 \\
\cline { 2 - 9 } & Min & $:$ & 108,7 & Min & $:$ & 83,8 & Min & $:$ & 98,2 \\
ME OFF & Max & $:$ & 89,2 & Max & $:$ & 63,8 & Max & $:$ & 78,2 \\
Generator ON & Average & $:$ & 99,5 & Average $:$ & 74,6 & Average $:$ & 89,0 \\
\hline
\end{tabular}


using the same modified Muffler.

Highlights of the muffler modification on the noise level were given as follows.

1) Modification of the Muffler on the main engine using an alternative barrier of plywood material could produce a transmission loss of as much as 24,94 $\mathrm{dB}$ and decreased the current system possessing $117,8 \mathrm{~dB}$ noise level to the very least of $92,9 \mathrm{~dB}$. Plywood is a material that can reduce the best noise among others with modifications to the expansion space, which initially $310 \mathrm{~cm}$ to $320 \mathrm{~cm}$, and modify the diameter of the expansion chamber, which was initially 98 to $110 \mathrm{~cm}$. Where the first Transmission Loss can reduce noise by 24,727 , after modification, it can reduce up to $24,94 \mathrm{~dB}$. And there is a change in contour noise mapping when compared to Existing conditions. The greater the modification, the greater the Transmission Loss generated to reduce noise on the Muffler.

2) When the ship is in Main engine OFF, and the ON Generator can also reduce noise up to 24,94 $\mathrm{dB}$. Where noise reaches $108,7 \mathrm{~dB}$, then modifying the Muffler on the Main engine with Plywood material can reduce noise to $83,8 \mathrm{~dB}$. For the Muffler parameters themselves, everything is the same. The only difference is the condition of the ship. But for noise mapping contours, there are differences with the condition of Main engine $\mathrm{ON}$ and Generator ON. For contour noise, there are differences when compared to Existing conditions.

3) Then for the Muffler placed on the tailpipe, it produces the biggest noise 107,3 dB. When modifying this Tail Pipe, noise can be reduced to $10,507 \mathrm{~dB}$. The condition of the ship when the Main engine $\mathrm{ON}$ and $\mathrm{ON}$ generator where after the modified condition produces noise up to $107,3 \mathrm{~dB}$ where previously the noise reaches $117,8 \mathrm{~dB}$ and when the vessel is in the main engine $\mathrm{OFF}$ and Generator $\mathrm{ON}$, where the biggest noise is $98.2 \mathrm{~dB}$ previously $108,7 \mathrm{~dB}$. For contour noise, there are differences when compared to Existing conditions.

\section{E. Noise Level based on the Standards}

Table 8 shows the compliance of the noise level prior to and after the modification of the Muffler against three Standards criteria comprise IMO, LR, and ABS. As seen from the table, the measured noise level of the existing machinery system onboard MV Natuna Express exceeds the Standards thresholds. After modification of the Muffler on the system, the noise level drops quite far below the threshold values. This signifies that the modified Muffler functions effectively as expected and efficiently reduced the noise in the existing machinery system.

Violation of the current system noise level to the Standards value might be due to several factors, including:

1) In the engine room, excessive noise can occur due to damping conditions that are not feasible.

2) Narrow and open engine room, so that the sound source not only comes from the engine room but also from outside sounds such as wind speed or passenger noise on the passenger deck because of the open windows and doors in the engine room.

3) The silencer of Muffler's exhaust gas main engine is not feasible and thinning.

\section{CONCLUSION}

Based on the finding of the study, it was deduced that

1) The noise condition of the Natuna Express Passenger High-Speed Express on the Gresik shipping channel - Bawean has a noise source, namely two main engine sets of ships and two generator sets with the Main engine $\mathrm{ON}$ conditions having an average noise of 115,4 dB and Generator ON when sailing and Main engine OFF and Generator ON when anchored have an average noise of $99,5 \mathrm{~dB}$. Even though the International standards for noise in the Engine Room such as IMO, LR, and ABS are 110 and 100 (ABS), with the results of the noise, it should not be allowed because it will disturb the noise of the crew of the ship because it is below the prescribed standard.

2) After making a recommendation on the Muffler modeling near the Main engine and near the Tail Pipe, it produces an efficient Muffler recommendation to reduce Transmission Loss. Where in figure R3 and L3 can reduce noise by 24,94 dB for Muffler near the Main engine, while for Muffler near the tailpipe can reduce by 10,507 $\mathrm{dB}$.

3) The modification of Muffler using Barrier with Plywood material: where the parameters used are only the length of the expansion space and the diameter of the expansion chamber. Where modification of the length of the expansion space is 310 to $320 \mathrm{~cm}$, and the diameter of the expansion chamber is 98 to $110 \mathrm{~cm}$ and produces a Transmission Loss of $24,727 \mathrm{~dB}$ to 24,94 Pipe resulting in a Transmission Loss of $10,507 \mathrm{~dB}$.

TABLE 8.

NOISE LEVEL COMPLIANCE CHECK

\begin{tabular}{cccccc}
\hline \multicolumn{2}{c}{ Average noise level } & & \multicolumn{3}{c}{ The Standards threshold value } \\
\cline { 1 - 1 } \cline { 5 - 6 } Existing system & Modified system & & IMO & LR & ABS \\
$(\mathrm{dB})$ & $(\mathrm{dB})$ & & $(\mathrm{dB})$ & $(\mathrm{dB})$ & $(\mathrm{dB})$ \\
115,4 & 90,5 & & 110 & 110 & 100 \\
\hline
\end{tabular}


With data as $\mathrm{dB}$ because of the longer and bigger the diameter in the barrier, the greater the Transmission Loss to reduce noise.

\section{REFERENCES}

[1] Dodi Apri Haryanto, "Experiment Study of Noise Reduction Diesel Exhaust Gas with Wet Damping Method," Surabaya, Sepuluh Nopember Institute of Technology, 2012.

[2] Gabriel Yusian Gadung, "Noise Level Analysis in Machine Rooms and Accommodation Spaces of Ketapang-Gilimanuk Crossing Boat Spaces," Surabaya, Ten November Institute of Technology, 2017.

[3] Ratih Dwilestari, "Noise Level Control in the KNP 329 crew due to the engine," in the 2nd Joint International Conference on "Sustainable Energy and Environment (SEE 2006), Bangkok, 2014.

[4] M. F. Fachrul, W. E. Yulyanto, and A. Merya, "Desain penyusunan peredam kebisingan menggunakan plywood, busa, tray dan sabut pada sumber statis," Makara Journal of Technology, vol. 15, no. 1, p. 150888, 2011.

[5] Rindianti Wibowo, "Analysis of Engine Room Noise Levels on KMP Ships. Muria, "Semarang, Diponegoro University, 2014.

[6] MSC 91/22 / Add.1 Annex I. (2012), "Code On Noise Levels On Boards Ships"

[7] C. R. Kothari, Research methodology: Methods and techniques. New Age International, 2004.

[8] Sunarsih, "Four Quadrant Thrust Generation Model with Bounded Dynamic Wake and Thrust Deduction Fractions," Doctoral Degree, Universiti Teknologi Malaysia, 2018.

[9] B.J Smith, R.J Peters and S. Owen "Acoustic and Noise Control 2nd Edition," London, Longman Group UK, 1996.

[10] A.P Peterson, "Handbook of Noise Measurements," In the 9th Edition, General Radion Inc., 1980.

[11] Noise Problem Analysis Part 2.pdf

[12] Odio Setyawan, "Analisa Tingkat Kebisingan Di Kamar Mesin Pada Kapal Cargo KM. Caraka Jaya Niaga III-17 Terhadap Kondisi Kerja Karyawan Dan Anak Buah Kapal (ABK)," Semarang, Universitas Diponegoro, 2012.

[13] Iwan Yahya, "Dasar-dasar Pengukuran kebisingan," Surakata, Universitas Sebelas Maret, 2002.
[14] Eko Julianto Sasono, "Pengukuran Tingkat Kebisingan Pada Kapal Coaster," Semarang, Universitas Diponegoro, 2007.

[15] Gun Gumelar Somantri, "Tingkat Kebisingan Pada Kapal Penangkap Ikan (Studi Kasus Pada Modern Boat Lift Net KM Omega Jaya Di Pulo Ampel Serang, Banten," Bandung, Institut Teknologi Bandung, 2014.

[16] Rilwanu Ahmad, "Model Analitik Muffler Absorptive Pada Ventilasi Udara," Surabaya, Institut Teknologi Sepuluh Nopember, 2015.

[17] Risna Dewi Enisa, "Intesitas Kebisingan Pada Kapal Gillnet di Pangkalan Pendaratan Ikan (PPI) Binuangeun Lebak Banten,"Bandung, Bandung Institute of Technology, 2016.

[18] Arif Syaiful, "Analisis Tingkat Kebisingan Pada Kamar Mesin dan Ruang Akomodasi Kapal Ro-Ro Penyebrangan Ketapang - Gilimanuk," Surabaya, Sepuluh Nopember Institute of Technology, 2004.

[19] Yudo Hartono, "Analisis Getaran dan Kebisingan Pada Motor Diesel Dengan Menggunakan Bahan Bakar Jelantah Ethyl Ester," Semarang, Universitas Diponegoro, 2012.

[20] Didik Kristiawan, "Analisis Kebisingan Sistem Ventilasi Kamar Mesin KR. Baruna Jaya VII ," Surabaya, Sepuluh Nopember Institute of Technology, 2004.

[21] Beny Cahyono, "Analisis Getaran dan Kebisingan Pada Motor Diesel Dengan Menggunakan Bahan Bakar Jelantah Ethyl Ester," Surabaya, Sepuluh Nopember Institute of Technology, 2002.

[22] Syawaluddin, "Pengujian Desain Muffler Untuk Mengurangi Emisi Suara Pada Mesin Diesel," Surabaya, Sepuluh Nopember Institute of Technology, 2004.

[23] Mastria Suandika, "Studi Awal Emisi Kebisingan Knalpo Dengan Profil Silinder Yang Dibuat Dari Material Titanium DenganMenggunakan Simulasi Metode Elemen Hingga," Medan, University of Sumatera Utara, 2007.

[24] Setiyo huboyo et al, "Buku Ajar Pengendalian Bising dan Bau," Semarang, University of Sumatera Utara, 2008 Universitas Diponegoro.

[25] Nono Triyono, "Studi Eksperimen Peredaman Kebisingan Gas Buang Motor Diesel Dengan Metode Peredaman Basah," Semarang, University of Sumatera Utara, 2005. Universitas Diponegoro. 